Available online/abstracted at http://www.biolineinternational.org.br/njps; www.ajol.info/journals.njps; www.cas.org

\title{
PREDICTION FORMULAE FOR LUNG FUNCTION PARAMETERS IN FEMALES OF SOUTH EASTERN NIGERIA.
}

\section{O. NKU; E. J. PETERS ${ }^{\text {; A. I. ESHIET }}$; S. A. BISONG and E. E. OSIM}

\author{
Department of Physiology, College of Medical Sciences, University of Calabar \\ ${ }^{1}$ Department of Medicine, University of Calabar Teaching Hospital, Calabar, \\ ${ }^{2}$ Department of Anaesthesiology, University of Calabar Teaching Hospital, Calabar. \\ e-mail: emeosim@yahoo.com
}

\begin{abstract}
Summary: This study was carried out to obtain normal lung function values for women in south eastern Nigeria with a view to establishing prediction equations for forced vital capacity (FVC), forced expiratory volume at the first second $\left(\mathrm{FEV}_{1}\right)$ and peak expiratory flow rate (PEFR). Lung function values were measured in 600 apparently healthy Nigerian women aged between 18 and 57 years. FVC and $\mathrm{FEV}_{1}$ were significantly related to height $(\mathrm{P}<0.001$ and $\mathrm{P}<0.01$ respectively) and body weight $(\mathrm{P}<0.01)$, PEFR was also related to age $(\mathrm{P}<0.01)$ and height $(\mathrm{P}<0.001)$. Prediction equations for the various lung function indices were as follows: $\mathrm{FVC}=0.145+(1.390 \mathrm{Ht})-(0.0076 \mathrm{age})+(0.0089 \mathrm{wt})$; $\mathrm{FEV}_{1}=0.240+(1.045 \mathrm{Ht})-(0.0055 \mathrm{age})+(0.0064 \mathrm{wt}) ; \mathrm{PEFR}=-38.80+(210.83 \mathrm{Ht})+(1.650 \mathrm{age})+$ $(0.252 \mathrm{wt})$. Ht is height in meters, wt. is body weight in kilograms and age is age in years. The ventilatory function indices were directly proportional to weight, height and to age. All the observed or measured lung function indices were not significantly different from their predicted values using the above prediction equations. Therefore, we conclude that lung function indices are influenced by the anthropometric parameters viz: age, body weight and height, and the prediction equations stated for FVC, FEV $_{1}$ and PEFR for Nigerian women between the ages 18 and 57 years are reliable.
\end{abstract}

Key Word: Lung function, Nigerian women, Prediction equation

\section{Introduction}

Lung function is influenced by such factors as sex, age, height, weight, environment and ethnicity (Anyanwu and Umeh, 1989; Mashalla et al., 1992). Lung function test provides a clearer understanding of pulmonary function in subjects of different races, age, sex, occupation and profession. If there are functional abnormalities in the respiratory system, the deviation from normal can form a basis for diagnosis and assessment of progress in the management of chronic ventilatory diseases (Ali, 1983). Lung function indices commonly used for the estimation of lung function are forced vital capacity (FVC), forced expiratory volume in the first second $\left(\mathrm{FEV}_{1}\right)$ and peak expiratory flow rate (PEFR).

Racial and ethnic differences in the values of pulmonary function have been reported in the past by some workers (Miller et al, 1970., Chehreh et al., 1973; Binder et al., 1976; Suzanne et al., 1994). Applying prediction formulae derived for Caucasians population always overestimated the values for black Africans (Njoku and Anah, 2004).
Studies for obtaining formulae for predicting normal lung function values for Nigerian women are rare. The few prediction formulae reported in literature considered very few numbers (less than 300) of females (Oduntan, 1970; Ali, 1983; Jaja, 1989; Suzanne et al., 1994). Only Singh et al., (1983) used a large population (more than 600) of women. Some other workers focused mainly on PEFR (Aderele and Oduwole, 1983; Jaja and Ojo, 1983; Jaja and Ogunberu, 1996; Njoku and Anah, 1999; Okoroma and Oviaore, 2000). In other studies the prediction equations were mainly in FVC and $\mathrm{FEV}_{1}$ (Oduntan, 1970; Patrick and Femi pearse, 1976; Onadeko et al., 1976; Ali, 1983; Ahuja and Ahuja, 1983). In all these studies, all the parameters that affect lung function namely; age, body weight and height were not taken into consideration in the formulation of prediction equations for lung function indices namely; FVC, FEV 1 and PEFR. For instance, Chehreh et al., (1973) and Singh et al., (1983) believed that gross weight contributes comparatively little to the resulting prediction formulae 
regardless of the race being studied, hence it was not considered in their prediction formula. Also, Suzanne et al., (1994) did not consider age as contributing significantly to any equation, so their equations were thus, derived without age as a factor.

In view of these omissions, it was the aim of this study to formulate prediction equations that contain all the parameters namely; age, body weight and height that affect lung function for women, since women are relatively understudied in comparison to men.

\section{Material and Methods}

A total of 600 apparently healthy females from south eastern Nigeria, particularly Calabar were used for the study. Their ages ranged from 18-57 years. They were undergraduates and civil servants engaged in non-dusty occupation and not exposed to any other air pollutants. All the subjects were nonsmokers. The study received the approval of all the participants and informed voluntary consent was obtained from each subject. Ethical clearance was obtained from the University of Calabar Teaching Hospital ethics committee.

\section{Procedure}

Subjects were called in groups and instructed on the test procedure. For easy understanding of the test procedure, demonstrations of the test were performed and all doubts cleared. All constricting clothing such as braziers were loosened to prevent alteration of test results from restricted thoracic expansion and abdominal mobility. A modified British medical Council respiratory disease questionnaire was administered to all subjects before the test was performed. The questionnaire recorded names, age, length of service, smoking habit, and any history of respiratory (pulmonary) disease. Height without shoes and weight with light clothing were measured and recorded. Forced vital capacity (FVC) and forced expiratory volume at the first second $\left(\mathrm{FEV}_{1}\right)$ were measured with a vitalograph spirometer (Vitalograph Limited Buckingham, England). Peak expiratory flow rate was measured with a mini-Wright peak flow meter (Air med Ltd. Harlow, England). Three trials were made per subject at one minute interval using each instrument and the best reading was taken. The spirometric records were obtained at body temperature and pressure saturated with water vapour.

\section{Statistical Analysis}

A linear multiple regression analysis to derive prediction equation for each of the lung function indices (FVC, $\mathrm{FEV}_{1}$ and PEFR) was done with a computer. The student's unpaired t-test was used to compare the means of any two indices; Chi-square test was used to test for significance between two proportions or percentages. $\mathrm{P}$ less than 0.05 was taken as significant.

\section{Results}

Table 1 shows spirometric formulae for predicting lung function parameters; namely; FVC, FEV ${ }_{1}$ and PEFR. Table 2 shows the comparison between measured and predicted values of FVC per age group. There was no statistically significant difference between the predicted values and the measured values. Table 3 shows the comparison between measured and predicted values of $\mathrm{FEV}_{1}$ per age group. There was no significant difference statistically between the measured and predicted values. Table 4 shows the comparison between measured values of PEFR per age group. There was also no statistically significant difference between the two.

Table 5 shows the correlation between anthropometric parameters (age, height and body weight) and the lung function parameters (FVC, $\mathrm{FEV}_{1}$ and PEFR). Age showed a positive correlation with PEFR $(\mathrm{P}<0.01)$. Height was positively related to FVC $(\mathrm{P}<0.001), \quad \mathrm{FEV}_{1} \quad(\mathrm{P}<0.01) \quad$ and $\quad$ PEFR $(\mathrm{P}<0.001)$. Body weight was also positively related to $\mathrm{FVC}(\mathrm{P}<0.01)$ and $\mathrm{FEV}_{1}(\mathrm{P}<0.05)$.

Table 1: formulae for predicting lung function parameters.

\begin{tabular}{lcc}
\hline Parameters & \multicolumn{1}{c}{ Predicted equation } & SEM \\
\hline FVC & $0.145+(1.390 \mathrm{Ht})-(0.0076$ age $)+(0.0089 \mathrm{wt})$ & 0.910 \\
FEV $_{1}$ & $0.240+(1.045 \mathrm{Ht})-(0.0055 \mathrm{age})+(0.0064 \mathrm{wt})$ & 0.754 \\
PEFR & $-38.80+(210.83 \mathrm{Ht})+(1.650 \mathrm{age})+(0.252 \mathrm{wt})$ & 87.302 \\
\hline
\end{tabular}

$H t=$ height in meters; $w t=$ body weight in $\mathrm{Kg}$; age = age in years. 
Prediction formulae for lung function parameters

Table 2: comparison between measured and predicted values of FVC per age group.

\begin{tabular}{cccc}
\hline Age group & $\begin{array}{c}\text { Predicted } \\
\text { values }\end{array}$ & $\begin{array}{c}\text { Measured } \\
\text { values }\end{array}$ & $\begin{array}{c}\text { Level of } \\
\text { significance }\end{array}$ \\
\hline $18-22$ & $2.68 \pm 0.027$ & $2.64 \pm 0.379$ & $\mathrm{NS}$ \\
$23-27$ & $2.72 \pm 0.154$ & $2.71 \pm 0.535$ & $\mathrm{NS}$ \\
$28-32$ & $2.70 \pm 0.166$ & $2.78 \pm 0.707$ & $\mathrm{NS}$ \\
$33-37$ & $2.70 \pm 0.139$ & $2.47 \pm 0.581$ & $\mathrm{NS}$ \\
$38-42$ & $2.66 \pm 0.168$ & $2.81 \pm 0.962$ & $\mathrm{NS}$ \\
$43-47$ & $2.46 \pm 0.102$ & $2.33 \pm 0.650$ & $\mathrm{NS}$ \\
$48-52$ & $2.46 \pm 0.201$ & $2.44 \pm 0.476$ & $\mathrm{NS}$ \\
$53-57$ & $2.42 \pm 0.265$ & $2.37 \pm 0.437$ & $\mathrm{NS}$ \\
\hline \multicolumn{3}{l}{ NS $=$ not significantly different }
\end{tabular}

Table 3: comparison between measured and predicted values of $F E V_{1}$ per age group.

\begin{tabular}{cccc}
\hline Age group & $\begin{array}{c}\text { Predicted } \\
\text { values }\end{array}$ & $\begin{array}{c}\text { Measured } \\
\text { values }\end{array}$ & $\begin{array}{c}\text { Level of } \\
\text { significance }\end{array}$ \\
\hline $18-22$ & $2.14 \pm 0.020$ & $2.13 \pm 0.326$ & $\mathrm{NS}$ \\
$23-27$ & $2.16 \pm 0.113$ & $2.16 \pm 0.446$ & $\mathrm{NS}$ \\
$28-32$ & $2.15 \pm 0.123$ & $2.17 \pm 0.624$ & $\mathrm{NS}$ \\
$33-37$ & $2.15 \pm 0.104$ & $1.96 \pm 0.472$ & $\mathrm{NS}$ \\
$38-42$ & $2.12 \pm 0.139$ & $2.20 \pm 0.696$ & $\mathrm{NS}$ \\
$43-47$ & $1.97 \pm 0.074$ & $2.01 \pm 0.706$ & $\mathrm{NS}$ \\
$48-52$ & $1.97 \pm 0.147$ & $2.10 \pm 0.457$ & $\mathrm{NS}$ \\
$53-57$ & $1.95 \pm 0.092$ & $1.88 \pm 0.282$ & $\mathrm{NS}$ \\
\hline \multicolumn{2}{l}{ NS $=$ not significantly different } & &
\end{tabular}

Table 4: comparison between measured and predicted values of PEFR per age group.

\begin{tabular}{cccc}
\hline Age group & Predicted values & Measured values & $\begin{array}{c}\text { Level of } \\
\text { significance }\end{array}$ \\
\hline $18-22$ & $342.79 \pm 3.240$ & $324.79 \pm 50.032$ & $\mathrm{NS}$ \\
$23-27$ & $360.91 \pm 18.230$ & $361 . .57 \pm 60.274$ & $\mathrm{NS}$ \\
$28-32$ & $366.58 \pm 15.750$ & $373.24 \pm 1.067$ & $\mathrm{NS}$ \\
$33-37$ & $375.08 \pm 16.026$ & $382.00 \pm 62.929$ & $\mathrm{NS}$ \\
$38-42$ & $382.62 \pm 20.252$ & $393.05 \pm 62.800$ & $\mathrm{NS}$ \\
$43-47$ & $374.47 \pm 10.998$ & $380.00 \pm 53.511$ & $\mathrm{NS}$ \\
$48-52$ & $390.85 \pm 17.243$ & $380.00 \pm 65.955$ & $\mathrm{NS}$ \\
$53-57$ & $403.94 \pm 26.892$ & $401.67 \pm 31.252$ & $\mathrm{NS}$ \\
\hline NS $=$ not significantly different & &
\end{tabular}

Table 5: correlation between anthropometric and lung function parameters.

\begin{tabular}{ccccccc}
\hline & \multicolumn{2}{c}{ FVC } & \multicolumn{2}{c}{ FEV $_{1}$} & \multicolumn{2}{c}{ PEFR } \\
Parameters & $\mathrm{r}$ & $\mathrm{p}$ & $\mathrm{r}$ & $\mathrm{p}$ & $\mathrm{r}$ & $\mathrm{p}$ \\
\hline Age $(\mathrm{yrs})$ & - & 0.207 & - & 0.253 & 0.211 & $* *$ \\
& 0.090 & & 0.081 & & & \\
Height $(\mathrm{m})$ & 0.239 & $* * *$ & 0.216 & $* *$ & 0.259 & $* * *$ \\
Weight $(\mathrm{Kg})$ & 0.182 & $* *$ & 0.161 & $*$ & 0.187 & 0.080 \\
\hline$*=P<0.05 ; * *=P<0.01 ; * * *=P<0.001$. & & &
\end{tabular}

\section{Discussion}

This study has established prediction formulae for lung function parameters in females of south eastern Nigeria. The subjects for this study were apparently healthy female adult Nigerians working or staying in Calabar. They were undergraduates and civil servants engaged in non-dusty occupations and not exposed to any known air pollutant. There was no cigarette smoker among the subjects studied.

This study shows that there was no statistically significant difference between the measured and predicted values of FVC, $\mathrm{FEV}_{1}$ 
and PEFR per age group. This indicates that the prediction equation formulated for lung function indices were reliable. Prediction equation established in some studies took into account only height (Suzanne et al., 1994). In their study, age did not contribute significantly to any equation and as such their equation was derived without age. In this study, we observed that age correlated positively with PEFR $(\mathrm{P}<0.01)$. This agrees with the report of Jaja and Ojo (1983); Onadeko et al., (1984); Ali and Vahalia (1991); Jaja and Fagbenro (1995); Njoku and Anah (2004).

It was also observed in this study that height was positively related to FVC $(\mathrm{P}<0.001)$ and $\mathrm{FEV}_{1} \quad(\mathrm{P}<0.01)$. This agrees with the work of Suzanne et al., (1994). Height also correlated positively with PEFR $(\mathrm{P}<0.001)$. We also observed that body weight was also positively related to $\mathrm{FVC}, \mathrm{FEV}_{1}$ and PEFR. This is in agreement with the report of Oduntan, (1970); Onadeko et al., (1979); Ali, (1983); Anyanwu and Umeh, (1989); Jaja and Fagbenro, (1995). However, Chehreh et al., (1973) and Singh et al., (1983), in their respective studies believed that gross body weight contributed comparatively little, hence their equation was derived without weight.

Since age, body weight and height were shown to significantly affect lung function, all these parameters were incorporated into the formulae for predicting the lung function indices, namely, FVC, FEV1 and PEFR. However, the racial differences in lung function values make it necessary for lung function measurement to be made for different ethnic groups in the world to determine normal values for each group. This study has attempted to determine normal values of lung function for women of south eastern Nigeria, particularly Calabar.

In conclusion, this study shows that all lung function indices are significantly related to age, height and body weight of subjects. Therefore, the formulae for predicting lung function indices namely; FVC, $\mathrm{FEV}_{1}$ and PEFR should incorporate age, height and body weight. The prediction equation obtained in this study produced lung function values that were not significantly different from the measured values. Therefore, the above prediction equations for FVC, FEV1 and PEFR for Nigerian women are reliable. This study provides an update, reference values for the use of Nigerian women. This updated prediction equation is important because the use of previously published equations could result in inaccurate estimates of pulmonary function, since some of the anthropometric parameters were left out.

\section{References}

Aderele, W. I. and Oduwole, O. (1983). Peak expiratory flow rate in healthy school children. Nig.J.Paed. 10:45-55

Ahuja, G. G. and Ahuja, I. S. (1983). A comparative study of ventilatory pulmonary function test in health and disease in Nigerain males. West. Afr. Med. J 2:61-65.

Ali, M. A. and Vahella, K. V. (1991). Some observation of peak expiratory flow in normal school children in northern Nigerian. West Afr. J. Med. 10:141-149

Ali, M. A. R. (1983). Ventilatory function in non-smoking healthy Nigerian adults. West.Afr.J. Med. 2:1-8

Anyanwu, C. H. and Umeh, B. U. (1989). Ventilatory pulmonary function study in healthy young Nigerian adults. Afr. $J$. Med. Sci. 18:257-262

Binder, R. E; Mitchell, C. A; Schrenberg, J. R; Bouhuys, A. (1976). Lung function among black and white children. Am. Rev. Resp. Dis. 114:955-999.

Chehreh, M. N; Young, R. C; Viaene, H; Ross, C. W; Scott, R. B. (1973).Spirometric standards for healthy inner-city black children. Am. J. Dis. Child. 126:159-163.

Jaja, S. I. (1989). Ventilatory function in adult Nigerians. Nig. J. Physiol. Sci. 5: 96-101

Jaja, S. I. and Fagbenro, A. O. (1995). Peak expiratory flow rate in Nigerian children. Afr. J. Med. Sci. 24:379-384

Jaja, S. I. and Ogungberu, S. A. (1996). Peak expiratory flow rate in Nigerians aged between 50 and 80 years. Nig. Qt. J. Hosp. Med. 6: 305-308

Jaja, S. I. and Ojo, G. O. (1983). Peak flow rate in young Nigerian adults. Nig. J. Physio. Sci. 1: 24-30

Mashalla, Y. J; Mesesa, P. C; Veenekalaas, R. J (1992). Changing relationship between $\mathrm{FEV}_{1}$ and height during adolescene. East Afr. Med. J. 69:240-243.

Miller, G. J.; Ashcroft, M. T.; Swan, A. V.; Beadnell, H. (1970). Ethnic variation in forced expiratory volume and FVC of African and Indian adults in Yuyana. Am. Rev. Resp. Dis. 102:979-981

Njoku, C. H. and Anah, C. 0. (2004). Reference values for peak expiratory flow rate in adults of African descent. Trop. Doctor. 34:135-140

Njoku, C. H. and Anah, C. O (1999). A new formula for predicting peak expiratory flow rate in adult Nigerians. Sahel med. $J$ 2: 39-44

Oduntan, S. A. (1970). Spirometric studies of normal and preoperative patients in Nigeria. Afr.J.Med.Sci. 1:79-84 
Okoroma, C. N. and Oviawe, O. (2000). Peak expiratory flow rate in Children living in Enugu urban area, Nigeria. Nig. Qt. J. Hosp. Med. 10: 171-174.

Onadeko, B. O.; Falase, A. O.; Ayene, O. (1976). Pulmonary function studies in Nigerian sportmen. Afr. J. Med and Med. Sci. 5:291-296

Onadeko, B. O; Iyun, A. A.; Sofowora, E. O.; Adanas, S. O. (1979). Ventilatory function in normal Nigerian school children. Afr. $J$. Med. Sci. 8:25-29

Onadeko, B. O; Iyun, A. A; Sofowora, E. O; Adanas, S. O (1984). Peak expiratory flow rate in normal Nigerian school children. Afr. J. Med. Sci. 13:25-32
Patrick, J. M and Femi-Pearse, D. (1976). Reference values of $\mathrm{FEV}_{1}$ and $\mathrm{FVC}$ in Nigerian men and women. A graphical summary. Nig. Med. J. 4:380-385

Singh, R.; Singh, H. J; Sirisinghe, R. G. (1992). FVC in Malaysians females. Jpn. J. Physiol. 42:407-414.

Suzanne, M. B.; David, A. A. and Mark, W., C. (1994). Pulmonary function test outcome in healthy Nawajo native American adolescents. Am. J. Resp. Crit. Care Med. 150:1150-1153

Received: $23 / 8 / 06$

Accepted: 4/12/06 